\title{
Biofilms of Black Tooth Stains: PCR Analysis Reveals Presence of Streptococcus mutans
}

\author{
Marília Teixeira COSTA ${ }^{1,2}$ \\ Miriam Leandro DORTA ${ }^{1}$ \\ Fátima RIBEIRO-DIAS ${ }^{1}$ \\ Fabiana Cristina PIMENTA ${ }^{1,3}$

\begin{abstract}
${ }^{2}$ Medical School, UFG - Federal University of Goiás, Goiânia, GO, Brazil
${ }^{3}$ Respiratory Diseases Branch, Centers for Disease Control and Prevention, Atlanta, GA, USA
\end{abstract} \\ ${ }^{1}$ Institute of Tropical Pathology and Public Health, UFG - Federal University of Goiás, Goiânia, GO, Brazil
}

\begin{abstract}
This study investigated the presence of the black-pigmented bacteria Prevotella nigrescens and Prevotella intermedia, the non-blackpigmented bacteria Actinomyces spp and particularly the cariogenic pathogen Streptococcus mutans in the dental biofilms of patients with or without black extrinsic tooth stains, using the multiplex polymerase chain reaction (PCR) technique. Analysis of the dental biofilms of patients with $(\mathrm{n}=26)$ or without $(\mathrm{n}=26)$ black tooth stains was performed using duplex PCR for the 16S ribosomal RNA gene (P. nigrescens, P. intermedia, Actinomyces spp) and glucosyltransferase-I gene for $S$. mutans. P. nigrescens and $S$. mutans were the most frequent bacteria detected in both groups. The least frequently detected were P. intermedia and Actinomyces spp. The similar bacterial composition of dental biofilms of black tooth stains and healthy tooth surfaces indicates that black tooth stains are not free of cariogenic bacteria.
\end{abstract}

Key Words: black tooth stain, dental caries, mutans streptococci, black-pigmented bacteria, PCR.

\section{INTRODUCTION}

Black extrinsic stains are biofilms formed on the smooth surfaces of teeth and are characterized by distinct dark spots comprised of insoluble iron salt and high concentrations of calcium and phosphate (1-4).

Black-pigmented bacteria (BPN) are present in the oral cavity (5) and are associated with black extrinsic tooth stains $(6,7)$. Among the BPNs, Prevotella intermedia and Prevotella nigrescens are dependent on the heme portion of hemoglobin as a required iron source for bacterial growth (8). P. nigrescens has specific surface proteins to bind to hemoglobin (9) and P. intermedia degrades hemoglobin to release the heme portion to the surface of the hemoglobin molecule and subsequently sequester iron for its growth (10). P. nigrescens and $P$. intermedia degrade oxyhaemoglobin to form (Fe(III) PPIX $)_{2} \mathrm{O}$ as an intermediate, which is converted into $\mathrm{Fe}$ (III)PPIX.OH by a depression in $\mathrm{pH}$. The low $\mathrm{pH}$ encourages cell-surface deposition of insoluble Fe(III) PPIX.OH which would act as a barrier against oxygen and reactive oxygen species, and also protect against $\mathrm{H}_{2} \mathrm{O}_{2}$ through its inherent catalase activity (3).

The presence of black extrinsic tooth stains has been associated with low occurrence of caries in patients with these stains when compared to patients presenting healthy tooth surfaces $(6,11,12)$, but this finding could not be confirmed by all authors $(13,14)$. Reasons for these results are not clear but it has been speculated that they are related to the specific oral microflora described in black stain-affected individuals (15). However, in studies about the microbiota of black extrinsic tooth stains, the presence of Streptococcus mutans, which is one of the main pathogens associated with dental caries $(16,17)$, has been little investigated.

The purpose of this study was to investigate the presence of the BPN $P$. nigrescens and $P$. intermedia, the non-black-pigmented bacteria Actinomyces spp, and particularly the cariogenic bacterium $S$. mutans, in the dental biofilms of patients with or without black extrinsic tooth stains, using the multiplex polymerase chain reaction (PCR) technique. 


\section{MATERIAL AND METHODS}

\section{Sample Collection}

This study involved 52 volunteer patients ( 25 females and 27 males) aged 9 to 50 years. The individuals were divided into two groups $(n=26)$ according to the presence or absence of black extrinsic tooth stains (groups BS and NBS, respectively). The investigation protocol was approved by the Ethics Committee for Human and Animal Medical Research of the Clinics Hospital at the Federal University of Goiás, Brazil. The samples were collected after the patients signed the informed consent form. Using sterile curettes, samples of the biofilms were collected from the vestibular and lingual surfaces of the teeth of each patient and transferred to $1.5 \mathrm{~mL}$ plastic tubes containing $500 \mu \mathrm{L}$ of saline solution. The samples were stored frozen at $-20^{\circ} \mathrm{C}$.

\section{Identification of the Bacteria by Multiplex PCR}

Genomic DNA was extracted using the Illustra blood genomic Prep Mini Spin Kit (GE Healthcare UK Limited, Buckinghamshire, UK). The 16S ribosomal RNA gene was used to detect $P$. nigrescens (5 'ATGAAACAAAGGTTTTCCGGTAAG3' 5'CCCACGTCTCTGTGGGGCTGCGA3' (804bp)) and P. intermedia (5'TTTGTTGGGGAGTAAAGCGGG3' and 5'TCAACATCTCTGTATCCTGCGT3' (575bp)) according to Tomazinho and Ávila-Campos (18). The targetgenetodetectS. mutans was the glucosyltransferase-I (5'ACTACACTTTCGGGTGGCTTGG3' and 5'CAGT ATAAGCGCCAGTTTCATC3'(517bp)) according to Franco and Franco et al. (19) and the 16S ribosomal RNA gene was used to detect Actinomyces spp 5'CTTAGCTTGCTAAGTATGCCGTTTAG3' and 5'CAGCTGACTTATACTCCCGAAATC3' (889bp) according to Saba et al. (7). Positive controls used in each experiment were the genomic DNA of S. mutans, $P$. nigrescens (ATCC 35406), P. intermedia (ATCC 25611) and Actinomyces spp (B19SC strain).

The multiplex PCR reaction was prepared with Invitrogen reagents (Invitrogen, Carlsbad, CA, USA): $2.5 \mu \mathrm{L}$ PCR 10X buffer solution, $1.75 \mu \mathrm{L} 50 \mathrm{mM}$ magnesium chloride solution, $0.5 \mu \mathrm{L} 10 \mathrm{mM}$ dNTP (DNA Polymerization Mix), $1.0 \mu \mathrm{L}$ each specific primer, $0.2 \mu \mathrm{L}$ Taqpolymerase and $13.55 \mu \mathrm{L}$ ultra-pure water. The total volume of each reaction was $25.0 \mu \mathrm{L}$ (22.5 $\mu \mathrm{L}$ of the PCR solution and $2.5 \mu \mathrm{L}$ of extracted DNA).
The following cycle was used: initial denaturation at $95^{\circ} \mathrm{C}$ for $5 \mathrm{~min}$; and denaturation at $95^{\circ} \mathrm{C}$ for $30 \mathrm{~s}$, annealing at $56^{\circ} \mathrm{C}$ for $1 \mathrm{~min}$, extension at $72^{\circ} \mathrm{C}$ for $1 \mathrm{~min}$ (40 cycles), and extension at $72^{\circ} \mathrm{C}$ for $5 \mathrm{~min}$. PCR products were then resolved on $2 \%$ agarose gel electrophoresis (Invitrogen), diluted in TBE buffer solution (tris-borate-EDTA buffer, $\mathrm{pH}=8.5$ ). The electrophoresis was performed in a TBE buffer solution at $100 \mathrm{~V}$, for $60 \mathrm{~min}$. The gel was stained with $15 \mu \mathrm{L}$ of GelRed $^{\text {TM }}$ (Biotium, Hayward, CA, USA) diluted in 100 $\mathrm{mL} 0.1 \mathrm{M} \mathrm{NaCl}$, under shaking for $30 \mathrm{~min}$ and the gel was visualized in a photo documentation system (Bio Rad Laboratories, Hercules, CA, USA).

\section{Statistical Analysis}

The data are presented as absolute numbers and frequencies (\%), which were compared between groups with Fisher's exact test, using GraphPad Prism software (GraphPad Inc., San Diego, CA, USA). The level of significance was set at $\mathrm{p}<0.05$.

\section{RESULTS}

At least one of the analyzed bacteria was detected in $61.5 \%(16 / 26)$ of the samples collected from patients with or without black tooth stains. Table 1 presents the four bacteria detected in the two groups. In group BS, $P$. nigrescens was the most frequently detected bacterium $(30.7 \%, 8 / 26)$. This frequency was similar $(\mathrm{p}=0.27)$ to that detected in the control patients $(46.1 \%, 12 / 26)$. $P$. intermedia was detected in $3.8 \%(1 / 26)$ of the patients from the group BS, showing no significant difference $(\mathrm{p}=0.59)$ of that detected in the group NBS $(11.5 \%$, $3 / 26)$. Among the non-pigment-producing bacteria, $S$. mutans was similarly detected in the two groups $(23.1 \%$

Table 1. Comparison of the prevalence of bacteria detected between patients with (group BS) and without (group NBS) black extrinsic tooth stains.

\begin{tabular}{|c|c|c|c|c|c|}
\hline \multirow[t]{2}{*}{ Bacteria } & \multicolumn{2}{|c|}{$\begin{array}{l}\text { Group BS } \\
(n=26)\end{array}$} & \multicolumn{2}{|c|}{$\begin{array}{l}\text { Group NBS } \\
\quad(n=26)\end{array}$} & \multirow[t]{2}{*}{$\mathrm{p}$} \\
\hline & $\mathrm{n}$ & $\%$ & $\mathrm{n}$ & $\%$ & \\
\hline P. nigrescens & 8 & 30.7 & 12 & 46.1 & 0.27 \\
\hline P. intermedia & 1 & 3.8 & 3 & 11.5 & 0.59 \\
\hline S. mutans & 6 & 23.0 & 8 & 30.7 & 0.72 \\
\hline Actinomyces spp & 5 & 19.2 & 3 & 11.5 & 0.42 \\
\hline
\end{tabular}


vs. $30.7 \%, \mathrm{p}=0.72)$ as was Actinomyces spp (19.2\% vs. $11.5 \%, \mathrm{p}=0.42)$.

Considering only positive samples for presence of bacteria (16 samples in each group), among the bacteria detected in group BS, P. nigrescens was the most frequent $(50.0 \%, 8 / 16)$ while $P$. intermedia was detected in only one sample $(6.2 \%, 1 / 16)$. The non-pigmented bacteria Actinomyces spp and $S$. mutans were detected in five and six samples, respectively $(31.2 \%$ and $37.5 \%, n=16$, Fig. 1A). Similar results were detected in the patients who did not exhibit black extrinsic stains, with $P$. nigrescens being the most frequently detected pigmented bacterium (75.0\%, 12/16), while $P$. intermedia was the least detected $(18.7 \%, 3 / 16)$. The non-pigmented bacteria Actinomyces spp and $S$. mutans were detected in 3 and 8 samples, respectively (18.7\% and 50.0\%, n=16, Fig. 1B).
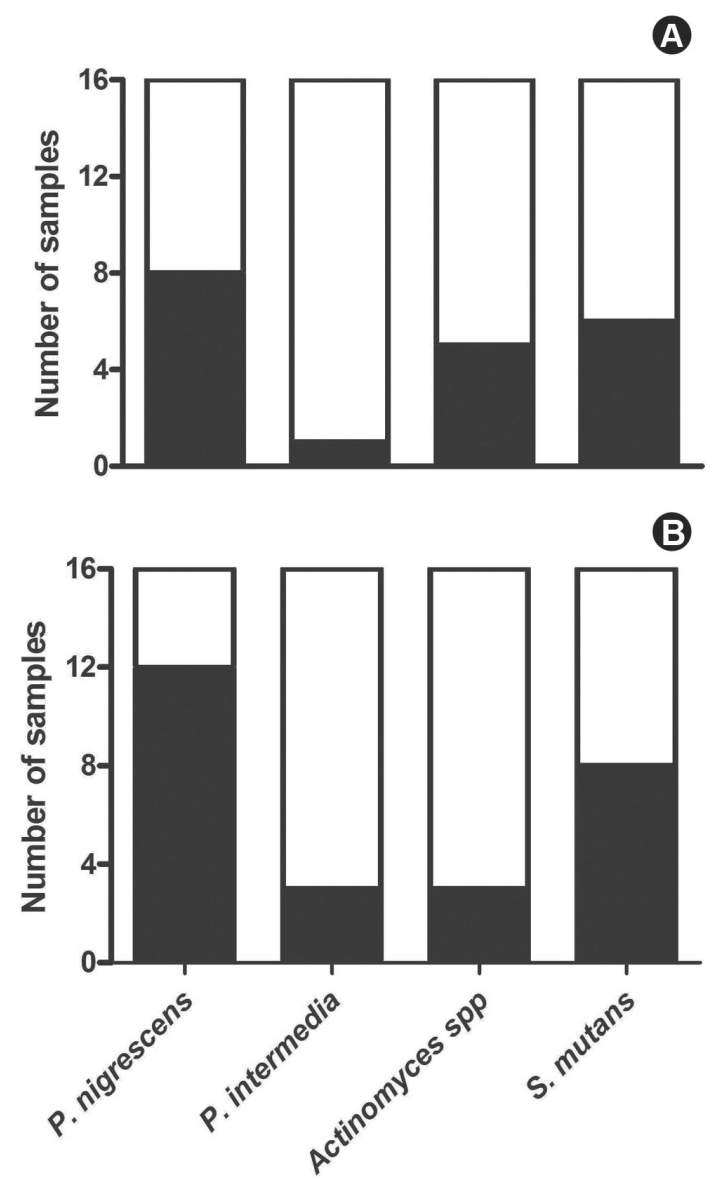

Figure 1. Bacteria-positive samples of patients with(A) or without (B) black tooth extrinsic stains were identified by the multiplex PCR technique. The data represent the number of samples analyzed $(\mathrm{n}=16)$ and the number of samples testing positive (filled columns) or negative (empty columns) for the above-mentioned bacteria.

\section{DISCUSSION}

This study showed that at least four bacteria can be detected in dental biofilms of black tooth stains, including black-pigmented and non-black pigmented cariogenic bacteria. The four analyzed bacteria ( $P$. nigrescens, $P$. intermedia, $S$. mutans and Actinomyces spp) were detected in a similar prevalence in samples from patients with or without black tooth stains, suggesting a similar bacterial colonization of dental biofilms of these patients. According to the literature $(5,20,21)$, among the 13 species of Prevotella, P. nigrescens and P. intermedia are the ones most frequently found in the oral cavity. $P$. nigrescens is indigenous microbiota of oral cavity whereas $P$. intermedia is related to periodontal disease. The high prevalence of $P$. nigrescens in the samples of group BS (30.7\%) and group NBS (46.1\%) is consistent with indigenous microbiota, confirming the prevalence of P. nigrescens over P. intermedia. Actinomyces spp nonpigmented bacterium was present in similar frequencies in groups BS and NBS (19.2\% vs. 11.5\%, respectively). These results do not support those reported by Saba et al. (7), who found that individuals with Actinomyces spp have a four-fold higher probability of presenting black stains than do individuals without these bacteria.

A similar prevalence of $S$. mutans was detected in the two groups (23.0\% vs 30.7\%). The high frequency of S. mutans found in samples of group BS differs from the results of Slots (6), who found that S. mutans was only detected in $5 \%$ of samples of biofilm from black stains. Slots (6) detected a correlation between the low number of $S$. mutans and the low rate of caries associated to the presence of black stains. However, Reid and Beeley (11) suggested that the reduction of the incidence of caries in individuals with black extrinsic tooth stains is due to the calcium and phosphate content of the biofilm of the stain. Analyzing the biofilm of black extrinsic tooth stains, some authors found a positive correlation between the presence of stains and the low incidence of caries $(2,12)$. However, other studies $(13,14)$ did not find such a correlation. The discordant findings can be related to the multifactorial nature of caries disease and the hypothesis that the positive correlation between the presence of black stains and the low incidence of caries is a simplistic and unifactorial evaluation. In a review of the fundamentals about black stains, its diagnosis and possible differential diagnoses, microbiology and therapy, Ronay and Attin (15) concluded that the reasons why the results are not clear about the black 
stains are related to the specific oral microflora of these stains. Another study (22) reinforced that chlorhexidine solution could cause some stains on teeth surface and confirms the great potential of using copaiba oil and chlorhexidine solution against the growth of $S$. mutans. The present study demonstrated that black pigmented bacteria ( $P$. nigrescens and $P$. intermedia) as well as cariogenic non-black pigmented bacteria (S. mutans and Actinomyces spp) can be detected in dental biofilms of patients carrying black tooth stains or not. The presence of $S$. mutans in the biofilm of black extrinsic stains confirms that the oral microbiota of these patients is not free of cariogenic bacteria. These findings indicate that analyzing the presence of different bacteria in dental biofilms is only the first step to understand the etiology of black tooth stains and its relation to caries status; other factors related to diet, hygiene techniques, caries status, and even other microorganisms in the oral cavity should also be examined.

\section{RESUMO}

O objetivo deste estudo foi investigar a presença das bactérias pigmentadoras de negro Prevotella nigrescens e Prevotella intermedia, da não pigmentadora de negro Actinomyces spp e particularmente a bactéria cariogênica Streptococcus mutans, no biofilme dentário de pacientes com ou sem manchas dentárias extrínsecas negras, utilizando a técnica multiplex PCR (reação em cadeia da polimerase). Análises do biofilme dentário de pacientes com manchas $(n=26)$ e sem manchas $(n=26)$ foram realizadas utilizando a multiplex PCR para o gene 16S RNA ribosomal (P. nigrescens, $P$. intermedia, Actinomyces spp) e o gene glucosiltransferase-I para $S$. mutans. $P$. nigrescens e $S$. mutans foram as bactérias mais frequentemente detectadas em ambos os grupos. As menos frequentemente detectadas foram $P$. intermedia e Actinomyces spp. A similaridade entre a composição bacteriana dos biofilmes dentários das manchas dentárias extrínsecas negras e das superfícies dentárias sem manchas indicam que as manchas dentárias extrínsecas negras não estão livres de bactérias cariogênicas.

\section{REFERENCES}

1. Theilade J, Slots J, Fejerskov O. The ultrastructure of black stain on human primary teeth. Scand J Dent Res 1973;81:528-532.

2. Reid JS, Beeley JA, Macdonald DG. Investigations into black extrinsic tooth stain. J Dent Res 1977;56:895-899.

3. Smalley JW, Silver J, Birss AJ, Withnall R, Titler PJ. The haem pigment of oral anaerobes Prevotella nigrescens and Prevotella intermedia is composed of iron (III) protoporphyrin IX in the monomeric form. Microbiol 2003;149:1711-1718.

4. Bandon D, Chabane-Lemboub A, Le Gall M. Exogenous black dental colorings at the child: black-stains. Arch Pediatr 2011;18:1343-1347

5. Yoshida A, Tachibana M, Ansai T, Takehara T. Multiplex polymerase chain reaction assay for simultaneous detection of black-pigmented Prevotella species in oral specimens. Oral Microbial Immunol 2005;20:43-46.

6. Slots J. The microbiota of black stain on human primary teeth. Scand J Dent Res 1974;82:484-490.

7. Saba C, Solidani M, Berlutti F, Vestri A, Ottolenghi L, Polimeni A. Black stains in the mixed dentition: a PCR microbiological study of the etiopathogenic bacteria. J Clin Pediatr Dent 2006;30:219224.

8. Soukos NS, Som S, Abernethy AD, Ruggiero K, Dunham J, Lee $\mathrm{C}$, et al.. Phototargeting oral black-pigmented bacteria. Antimicrob Agents Chemother 2005;49:1391-1396.

9. Guan SM, Nagata H, Maeda K, Kuboniwa M, Minamino N, Shizukuishi S. Purification and characterization of a hemoglobinbinding outer membrane protein of Prevotella intermedia. FEMS Microbiol Lett 2004;235:333-339.

10. Guan SM, Nagata H, Shizukuishi A, Wu JZ. Degradation of human hemoglobin by Prevotella intermedia. Anaerobe 2006;12:279282.

11. Reid JS, Beeley JA. Biochemical studies on the composition of gingival debris from children with black extrinsic tooth stain. Caries Res 1976;10:363-369.

12. Koch MJ, Bove M, Schroff J, Perlea P, Garcia-Godoy F, Hans-Jörg S. Black stain and dental caries in schoolchildren in Potenza, Italy. J Dent Child 2001;68:353-355.

13. Gasparetto A, Conrado CC, Maciel SM, Miyamoto EY, Chicarelli M, Zanata RL. Prevalence of black tooth stains and dental caries in Brazilian schoolchildren. Braz Dent J 2003;14:157-161.

14. Gallardo VP, Cencillo CP. Tinción cromógena: un problema habitual en la clínica pediátrica. An Pediatr 2005;62:258-260.

15. Ronay V, Attin T. Black stain - a review. Oral Health Prev Dent 2011;9:37-45.

16. Hamada S, Slade HD. Biology, immunology and cariogenicity of Streptococcus mutans. Microbiol Mol Biol Rev 1980;44:331-384.

17. Loesche WJ. Role of Streptococcus mutans in human dental decay. Microbiol Rev 1986;50:353-380.

18. Tomazinho LF, Ávila-Campos MJ. Detection of Porphyromonas gingivalis, Prevotella intermedia and Prevotella nigrescens in chronic endodontic infection. Oral Surg Oral Med Oral Pathol Oral Radiol Endod 2007;103:285-288.

19. Franco e Franco TCC, Amoroso P, Marin JM, Ávila FA. Detection of Streptococcus mutans and Streptococcus sobrinus in dental plaque samples from Brazilian preschool children by polymerase chain reaction. Braz Dent J 2007;18:329-333.

20. Ashimoto A, Chen C, Bakker I, Slots J. Polymerase chain reaction of 8 putative periodontal pathogens in subgingival plaque of gingivitis and advanced periodontitis lesions. Oral Microbiol Immunol 1996;11:266-273.

21. Gharbia SE, Haapasalo M, Shah H, Kotiranta A, Lounatmaa K. Characterization of Prevotella intermedia e Prevotella nigrescens isolates from periodontic and endodontic infections. J Periodontol 1994;65:56-61.

22. Pieri FA, Mussi MCM, Fiorini JE, Moreira MAS, Schneedorf JM. Bacteriostatic effect of copaiba oil (Copaifera officinalis) against Streptococcus mutans. Braz Dent J 2012;23:36-38.

Received April 13, 2012 Accepted September 25, 2012 